\title{
HUBUNGAN DISLIPIDEMIA DAN KEJADIAN PENYAKIT JANTUNG KORONER
}

\author{
Ma'rufi, $\mathrm{R}^{1}$, Rosita, L. ${ }^{2}$ \\ ${ }^{1}$ Mahasiswa Pendidikan Dokter Fakultas Kedokteran Universitas Islam Indonesia \\ ${ }^{2}$ Departemen Patologi Klinik, Fakultas Kedokteran Universitas Islam Indonesia, Yogyakarta
}

\begin{abstract}
ABSTRAK
Latar Belakang

Penyakit jantung koroner (PJK) merupakan penyebab kematian utama di dunia. Penelitian lain yang dilakukan sebelumnya memberikan hasil bahwa dislipidemia merupakan faktor risiko tersering penyakit jantung koroner.

\section{Tujuan}

Tujuan penelitian ini untuk mengetahui hubungan antara dislipidemia (LDL) dan kejadian penyakit jantung koroner pada penderita di RS PKU Muhammadiyah Yogyakarta periode 1 Januari 2010 - 31 Desember 2011. Penelitian ini menggunakan desain cross-sectional, dan pengambilan sampel menggunakan metode konsekutif sampling. Subyek penelitian adalah laki-laki dan perempuan yang berumur lebih dari 45 tahun dan mempunyai data profil lipid yang lengkap. Subyek penelitian dibagi menjadi 2 kelompok, 32 subyek dengan penyakit jantung koroner dan 32 subyek tanpa penyakit jantung koroner. Analisis data dilakukan menggunakan uji chi-square.
\end{abstract}

\section{Hasil}

Persentase pasien dengan kadar LDL $>130 \mathrm{mg} / \mathrm{dL}$ pada kelompok PJK adalah 65,6\% dan pada kelompok non-PJK adalah 40,6\% ( $\mathrm{p}=0,045$ dan $\mathrm{RP}=1,68 ; 95 \% \mathrm{CI}=1,01-7,7$ ).

\section{Kesimpulan}

Penelitian ini menunjukkan hasil bahwa kadar LDL >130mg/dL berhubungan dengan faktor risiko kejadian penyakit jantung koroner pada subyek penelitian

Kata kunci : Penyakit jantung koroner, dislipidemia, LDL 


\section{ABSTRACT}

\section{Background}

Coronary heart disease is the most common cause of death in the world. The previous study

indicated that dyslipidemia is the most common risk factor for coronary heart disease.

\section{Objective}

The aim of this study was to examine whether there is association between dyslipidemia $(L D L)$ and incidence of coronary heart disease in PKU Muhammadiyah Yogyakarta hospital during the period from 1 January 2010 to 31 December 2011.

\section{Methods}

This was cross-sectional study with consecutive sampling. The subjects for this study were men and women aged $>45$ years and that have complete lipid profile. The subject of the study is devided into 2 groups, 32 subjects with coronary heart disease, and 32 subjects without coronary heart disease. The association was analyzed using chi-square tests.

\section{Results}

The percentage of patients with $L D L>130 \mathrm{mg} / \mathrm{dL}$ in subjects with coronary heart disease was $65,6 \%$ and in subjects without coronary heart disease was 40,6\% ( $p=0,045$ and $R P=1,68 ; 95 \%$ $C I=1,01-7,7)$.

\section{Conclusion}

The result indicated that association risk factor of coronary heart disease in this study was LDL $>130 \mathrm{mg} / \mathrm{dL}$

Keywords: Coronary heart disease, dyslipidemia, $L D L$.

\section{LATAR BELAKANG}

Penyakit jantung masih menjadi penyebab kematian dan kecacatan terbesar di dunia. ${ }^{1,2}$ Jenis penyakit jantung yang merupakan penyebab kematian utama di dunia adalah penyakit jantung koroner., Berdasarkan data dari badan kesehatan dunia (WHO) disebutkan bahwa penyakit jantung koroner (PJK) merupakan penyebab utama kematian pada tahun 2002, yang meliputi $12,2 \%$ (7,2 juta) kematian di seluruh dunia. ${ }^{5}$ Hasil pencatatan dan pelaporan rumah sakit (SIRS/ Sistem

Informasi Rumah Sakit) di Indonesia, menunjukkan total kasus rawat jalan PJK sebanyak 78.330 kasus dan total kasus rawat inap sebanyak 31.853 kasus. ${ }^{6}$ Jenis penyakit ini terdiri dari unstable angina, $S T$ elevation myocardial infarction (STEMI), dan Non ST elevation myocardial infarction (NSTEMI). ${ }^{7}$

Faktor risiko utama PJK diantaranya adalah dislipidemia. ${ }^{8.9}$ Dislipidemia merupakan suatu kondisi dimana terjadi 
abnormalitas kadar lipid di dalam darah, hubungan antara low density lipoprotein diantaranya peningkatan kadar kolesterol, (LDL) dan kejadian penyakit jantung LDL (Low Density Lipoprotein), dan kadar koroner di Indonesia.

trigliserida, serta penurunan kadar HDL Tujuan dari penelitian ini adalah (High Density Lipoprotein). ${ }^{10,11}$ Menurut untuk mengetahui hubungan antara kadar penelitian kedokteran molekuler terbaru, low density lipoprotein (LDL) dan kejadian didapatkan bahwa jenis dislipidemia yang PJK. Diharapkan penelitian ini dapat paling berbahaya adalah dislipidemia memberikan informasi apakah kadar LDL aterogenik. Deposit kolesterol LDL dapat digunakan sebagai faktor risiko PJK, dislipidemia aterogenik pada dinding memberikan masukan bagi klinisi untuk pembuluh darah arteri menjadi salah satu pemberian terapi PJK, dan sebagai dasar penyebab terjadinya disfungsi endotel pemikiran untuk melakukan penelitian sebagai proses awal terbentuknya plak selanjutnya.

aterosklerosis. $^{12,13}$

Lipid, khususnya low density METODE PENELITIAN lipoprotein (LDL) saat ini mulai banyak Penelitian ini adalah penelitian diteliti sebagai nilai prediksi pada PJK, observasional analitik dengan desain mengingat perannya dalam proses penelitian cross-sectional. Penelitian ini aterogenesis. $^{14}$ Salah satunya adalah menggunakan data sekunder dari RS PKU penelitian yang dilakukan Imano et al Muhammadiyah Yogyakarta. Populasi pada (2011). Hasil dari penelitian ini menunjukkan bahwa pada populasi di Jepang terdapat hubungan yang kuat antara kadar LDL >80 mg/dL dengan risiko PJK. ${ }^{15}$ Oleh karena itu, seiring dengan meningkatnya angka prevalensi dan mortalitas penyakit jantung koroner di Indonesia, penulis mencoba mengkaji penelitian ini adalah seluruh pasien RS PKU Muhammadiyah Yogyakarta periode 1 Januari 2010 - 31 Desember 2011 baik laki-laki maupun perempuan yang berumur lebih dari 45 tahun dan mempunyai hasil pemeriksaan profil lipid. Subyek penelitian dibagi menjadi 2 kelompok, kelompok dengan PJK dan kelompok tanpa PJK. 
Pasien PJK dinyatakan oleh dokter berdasarkan manifestasi klinis dan elektro kardio grafi (EKG). Perubahan EKG dapat meliputi hiperakut $\mathrm{T}$, elevasi segmen ST, depresi segmen ST, gelombang Q patologis, kembalinya segmen ST pada garis isoelektris dan inversi gelombang $\mathrm{T} .{ }^{16} \mathrm{LDL}$ atau low density lipoprotein (LDL) merupakan salah satu pemeriksaan profil lipid yang terdiri dari pemeriksaan kadar kolesterol total, LDL, HDL, dan kadar uji chi-square dengan menggunakan program SPSS 15.0 for Windows.

\section{HASIL}

Dilakukan analisis pada 64 sampel, yang terdiri dari 32 sampel dengan diagnosis PJK dan 32 sampel dengan diagnosis tanpa PJK. Pada Tabel 1 menunjukkan distribusi PJK berdasarkan umur, dari tabel tersebut didapatkan hasil bahwa PJK ditemukan paling banyak pada

Tabel 1. Karakteristik Subyek Penelitian menurut Umur dan Jenis Kelamin

\begin{tabular}{|c|c|c|c|c|c|c|}
\hline \multirow[t]{2}{*}{ Karakteristik } & \multicolumn{2}{|c|}{ PJK } & \multicolumn{2}{|c|}{ Non-PJK } & \multicolumn{2}{|c|}{ Total } \\
\hline & Jumlah & $\%$ & Jumlah & $\%$ & Jumlah & $\%$ \\
\hline Umur & & & & & & \\
\hline 45-64 tahun & 18 & 56,2 & 24 & 75,0 & 42 & 65,6 \\
\hline$\geq 65$ tahun & 14 & 43,8 & 8 & 25,0 & 22 & 34,4 \\
\hline Jumlah & 32 & 100 & 32 & 100 & 64 & 100 \\
\hline Jenis Kelamin & & & & & & \\
\hline Laki-laki & 23 & 71,8 & 18 & 56,2 & 40 & 62,5 \\
\hline Perempuan & 9 & 28,2 & 14 & 43,8 & 24 & 37,5 \\
\hline Jumlah & 32 & 100 & 32 & 100 & 64 & 100 \\
\hline
\end{tabular}

trigliserid. Pemeriksaan profil lipid umur 45 - 64 tahun (56,2\%). Hasil ini didapatkan dari pemeriksaan laboratorium. berbeda dengan penelitian yang dilakukan Kriteria dislipidemia untuk kadar LDL oleh Centers for Disease Control and adalah $>130 \mathrm{mg} / \mathrm{dL} .{ }^{17}$ Dalam penelitian ini, Prevention pada tahun 2011, penelitian data tentang PJK dan kadar LDL diperoleh tersebut menyebutkan bahwa PJK diderita dari data sekunder atau rekam medis.

Seluruh pasien PJK yang tahun. ${ }^{18}$

mengkonsumsi obat penurun lemak Pada Tabel 1 juga menunjukkan dikeluarkan dari sampel penelitian. hasil bahwa jumlah penderita PJK dengan Selanjutnya, perbedaan kadar LDL pada jenis kelamin laki-laki (71,8\%) lebih kedua kelompok dianalisis menggunakan banyak dari pada penderita PJK dengan 
jenis kelamin perempuan. Hal ini sesuai dengan penelitian yang dilakukan oleh Centers for Disease Control and Prevention pada tahun 2011, yang menunjukkan bahwa PJK lebih banyak diderita oleh jenis kelamin laki-laki dibandingkan dengan jenis kelamin perempuan. ${ }^{18}$

Pada Tabel 2 terlihat kadar LDL pada kelompok dengan PJK dan kelompok tanpa PJK. Terlihat bahwa pada kelompok kepercayaan 95\% CI (1,01-7,7). Hasil yang didapat menunjukkan bahwa kadar LDL $>130 \mathrm{mg} / \mathrm{dL}$ merupakan faktor risiko terjadinya PJK pada subyek penelitian yang diteliti.

\section{PEMBAHASAN}

Hasil yang didapat, menunjukkan bahwa kadar LDL >130mg/dL merupakan faktor risiko terjadinya PJK pada subyek

Tabel 2. Pengujian Chi-Square Subyek Penelitian Terhadap LDL

\begin{tabular}{|c|c|c|c|c|c|c|c|c|c|}
\hline \multirow{3}{*}{ LDL (mg/dL) } & \multicolumn{4}{|c|}{ Diagnosis } & \multirow{3}{*}{ Jumlah } & \multirow{3}{*}{$\mathbf{P}$} & \multirow{3}{*}{$\begin{array}{c}\text { CI } \\
95 \% \\
\end{array}$} & \multirow{3}{*}{$X^{2}$} & \multirow{3}{*}{$\boldsymbol{R P}$} \\
\hline & \multicolumn{2}{|c|}{ PJK } & \multicolumn{2}{|c|}{ Non-PJK } & & & & & \\
\hline & n & $\%$ & n & $\%$ & & & & & \\
\hline LDL >130 & 21 & 65,6 & 13 & 40,6 & 34 & & & & \\
\hline $\mathrm{LDL} \leq 130$ & 11 & 34,4 & 19 & 59,4 & 30 & 0,045 & $1,011-$ & 4 & 1,684 \\
\hline Jumlah & 32 & 100 & 32 & 100 & 64 & & & & \\
\hline
\end{tabular}

dengan PJK, jumlah subyek penelitian yang memiliki kadar LDL lebih besar dari >130 $\mathrm{mg} / \mathrm{dL}$ lebih banyak $(65,6 \%)$ dibandingkan subyek penelitian yang memiliki kadar LDL $\leq 130 \mathrm{mg} / \mathrm{dL}(34,4 \%)$. Hasil analisis menggunakan uji Chi-Square didapatkan hasil p-value adalah 0,045 dan nilai Confidence Interval yang didapatkan adalah CI $95 \%(1,01-7,7)$, sedangkan nilai $x^{2}$ hitung adalah 4. Dari hasil tersebut maka disimpulkan bahwa terdapat hubungan antara kadar LDL >130 mg/dL dan kejadian PJK pada subyek penelitian yang diteliti. Berdasarkan perhitungan rasio prevalensi, didapatkan hasil 1,68 dengan interval penelitian yang diteliti. Hasil penelitian yang kami lakukan sejalan dengan penelitian yang dilakukan oleh Imano et al (2011) yang diikuti oleh 8.131 subyek penelitian. Penelitian ini menunjukkan hasil bahwa terdapat hubungan yang kuat antara kadar LDL > $80 \mathrm{mg} / \mathrm{dL}$ dengan risiko PJK pada populasi di Jepang. ${ }^{15}$ Penelitian lainnya yang dilakukan oleh Sarah et al (2012) yang diikuti 20.000 subyek penelitian menunjukkan adanya hubungan erat antara partikel LDL dengan kejadian penyakit vaskular atau pembuluh darah pada subyek penelitian yang diteliti. ${ }^{19}$ Dalam penelitian ini kadar LDL merupakan 
variabel yang bermakna, namun menurut Kinosian et al (1994), rasio total kolesterol dengan kadar LDL bernilai lebih prediktif terhadap penyakit jantung koroner, dibandingkan dengan kadar LDL itu sendiri. $^{20}$

Hubungan antara LDL dan PJK terdapat dalam proses aterosklerosis. Proses aterosklerosis dimulai dengan kerusakan atau disfungsi endotel pada dinding arteri. Kemungkinan penyebab dari kerusakan endotel ini dapat deisebabkan oleh meningkatnya level low-density liporotein (LDL). Bila kadar LDL tinggi, maka kolesterol yang diangkut oleh LDL dapat mengendap pada lapisan subendotelial, oleh sebab itu LDL bersifat aterogenik, yaitu bahan yang dapat menyebabkan terjadinya aterosklerosis. Ruang subendotelial ini mempunyai proteksi oleh antioksidan yang rendah, sehingga LDL mudah memasuki ruangan ini. ${ }^{14,21}$

Setelah LDL masuk ke dalam sel endotel, LDL kemudian dioksidasi dan akhirnya terbentuk LDL yang teroksidasi. Bukti terbaru menjelaskan bahwa LDL yang teroksidasi ini berkontribusi dalam kerusakan endotel, migrasi monosit dan limfosit ke tunika intima, merubah monosit menjadi makrofag, dan kejadian-kejadian lainnya yang terjadi dalam kemajuan proses aterosklerosis. Pada suatu penelitian, kenaikan serum LDL pada binatang dapat menyebabkan aterosklerosis tanpa adanya faktor risiko lain. Mekanismenya adalah karena deposit LDL di dinding pembuluh darah arteri bersifat pro-inflamasi, suatu respon inflamasi kronik yang dapat mengawali timbulnya aterosklerosis. ${ }^{12,21}$

\section{KESIMPULAN}

Terdapat hubungan antara kadar $\mathrm{LDL}>130 \mathrm{mg} / \mathrm{dL}(\mathrm{p}=0,045$ dan $\mathrm{RP}=1,68$; 95\% $\mathrm{CI}=1,01-7,7) \quad$ dengan kejadian penyakit jantung koroner pada penderita yang dirawat di RS PKU Muhammadiyah Yogyakarta periode 1 Januari 2010 - 31

Desember 2011.

\section{Daftar Pustaka}

1. David WB, George AM. An Overview of Cardiovascular Disease Burden in The United States. Health Aff. 2007;26(1):3848.

2. Mackenbach JP, Cavelaars AE, Kunst AE, Groenhof F. Socioeconomic Inequalities in Cardiovascular Disease Mortality: An International Study. Eur Heart J. 2000;21(14):1141-1151.

3. Center for Disease Control and Prevention, Heart Disease, 2011, <http://www.cdc.gov/heartdisease/>, accessed Dec.25, 2011.

4. Nora LK, Kate MS. Coronary Heart Disease and Stroke Deaths - United States. Supplements. 2011;60(1):62-66.

5. World Health Organization, Global Atlas on Cardiovascular Disease Prevention and Control, 2011, 
$<$ http://www.who.int/cardiovascular_diseas es/en/>, accessed Dec. 15, 2011.

6. Departemen Kesehatan Republik Indonesia. Profil Kesehatan Indonesia 2008. Jakarta: Pusat Data dan Informasi; 2009.

7. Anthony SF, Dennis LK, L. Longo, Eugene B, Stephen LH, J. Larry Jameson, Joseph L. Harrison's Principles of Internal Medicine volume II $\left(18^{\text {th }}\right.$ ed). United States of America: McGraw-Hill; 2012.

8. Kathryn LM, Sue EH. Pathophysiology The Biologic Basis for Disease in Adults and Children $\left(5^{\text {th }}\right.$ ed). United States of America: Elsevier Mosby; 2006

9. Arthur SL. Dyslipidemia and Risk of Coronary Heart Disease: Role of Lifestyle Approaches for Its Management. American Journal of Lifestyle Medicine. 2009;3(4):257-273.

10. Dorland. Dorland's Illustrated Medical Dictionary $\left(29^{\text {ed }}\right.$ ed). Philadelphia: W.B. Saunders Company; 2002.

11. Kiran M. Atherogenic Dyslipidemia: Cardiovascular Risk and Dietary Intervention. Lipids. 2010;45(10):907-914.

12. Sany RS. Dislipidemia Sebagai Faktor Risiko Utama Penyakit Jantung Koroner. Cermin Dunia Kedokteran. 2009;36(3):181184.

13. Iman S. Penyakit Jantung Koroner Panduan Bagi Masyarakat Umum, Jakarta: Penerbit PT Gtamedia Pustaka Utama; 2001.

14. Mirjana D, Edita S, Biljana V, Suncica KD, Velibor C. Lipids and Atherosclerosis. Jugoslov Med Biohem. 2006;25(4):325333.
15. Imano H, Noda H, Kitamura A, Sato S, Kiyama M, Sankai T, Iso H. Low-Density Lipoprotein Cholesterol and Risk of Coronary Heart Disease Among Japanese Men and Women: The Circulatory Risk in Communities Study (CIRCS). Preventive Medicine, 2011;52(5):381-386.

16. PERKI. Pedoman Perhimpunan Dokter Spesialis Kardiovaskuler Indonesia (PERKI) Tata Laksana Sindroma Koroner Akut dengan ST Elevasi.Jakarta: PP PERKI; 2004.

17. Goldberg, Anne Carol, Dyslipidemia (Hyperlipidemia)., 2008, <http://www. merckmanuals.com/professional/endocrine _and_metabolic_disorders/lipid_disorders/d yslipidemia.html.>, accessed Sept. 8, 2012.

18. Centers for Disease Control and Prevention. Prevalence of Coronary Heart DiseaseUnited States, 2006-2010. MMWR. Morbidity and Mortality Weekly Report. 2011;60(40) 1377-1381.

19. Sarah $\mathrm{P}$, Alisson O, Robert $\mathrm{C}$, Jemma $\mathrm{CH}$, Michael RH, James O, Jane A, Collins, Rory C. Lipids and Lipoproteins and Risk of Different Vascular Events in The MRC/BHF Heart Protection Study. Circulation. 2012;125(20):2469-2478.

20. Bruce K, Henry G, Gonzalo G. Cholesterol and Coronary Heart Disease: Predicting Risks by Levels and Ratios. Annals of Internal Medicine. 1994;121(9):641-647.

21. Stuart IF. Human Physiology ( $7^{\text {th }}$ ed), New York: McGraw-Hill Companies; 2002. 